\title{
First Nesting Records for the Short-eared Owl, Asio flammeus, on Banks Island, Northwest Territories: Evidence of Range Expansion to Arctic Islands in Canada
}

\author{
Cynthia Marjorie Smith ${ }^{1,2}$, Norman Andrew Lawrence ${ }^{1,3}$, and Rosemary Anne Buck ${ }^{1,3}$ \\ ${ }^{1}$ Parks Canada, Aulavik National Park of Canada, Sachs Harbour, Northwest Territories X0E 0Z0 Canada; e-mail: cyndi.smith \\ @pc.gc.ca \\ ${ }^{2}$ Current address: P.O. Box 70, Mountain View, Alberta T0K 1N0 Canada \\ ${ }^{3}$ Current address: P.O. Box 5457, Haines Junction, Yukon Y0B 1L0 Canada
}

Smith, Cynthia M., Norman A. Lawrence, and Rosemary A. Buck. 2013. First nesting records for the Short-eared Owl, Asio flammeus, on Banks Island, Northwest Territories: evidence of range expansion to arctic islands in Canada. Canadian Field-Naturalist 127(2): 185-188.

Two Short-eared Owl, Asio flammeus, nests were discovered in the summer of 2000 along the Thomsen River in Aulavik National Park of Canada on Banks Island, Northwest Territories. One other sighting of a Short-eared Owl suggests the possibility of a third breeding pair. These nests are the first confirmed breeding evidence from islands in the Canadian Arctic Archipelago.

Key Words: Short-eared Owl; Asio flammeus; nest; range expansion; Aulavik National Park of Canada; Banks Island; Northwest Territories

Short-eared Owls, Asio flammeus, are highly nomadic, following fluctuating food resources and frequently breeding and wintering where numbers of small mammals are particularly high (Wiggins et al. 2006). Shorteared Owls are known to breed in suitable habitat throughout Canada, with the exception of the Canadian Arctic Archipelago (Committee on the Status of Endangered Wildlife in Canada 2008*). Suitable habitat in the Arctic includes coastal estuaries, tundra with areas of small willows and dense grasslands (Committee on the Status of Endangered Wildlife in Canada 2008*).

Since the mid-1970s, a number of biological surveys have listed species of birds for Banks Island, Northwest Territories (Wilkinson et al. 1977*; Zoltai et al. 1980*; Henry and Mico 1997*), but none documented the presence of Short-eared Owls. Raptors include the fairly common Snowy Owl (Bubo scandiacus) and Rough-legged Hawk (Buteo lagopus), the less common Peregrine Falcon (Falco peregrinus), and the rare Gyrfalcon (Falco rusticolus). In the summer of 2000, however, Short-eared Owls were documented for the first time on Banks Island.

\section{Observations}

The first of two Short-eared Owl nests was discovered on 25 June 2000 near Green Cabin on the Thomsen River $\left(73.236^{\circ} \mathrm{N}, 119.545^{\circ} \mathrm{W}\right)$ in Aulavik National Park of Canada (Figure 1) and reported to park authorities. Green Cabin is a patrol/research cabin upstream of Dissection Creek. On 27 June, when we approached the nest, the male flew off from a location about $100 \mathrm{~m}$ from the nest. A subsequent inspection of the site where the male had flown up from revealed the head of a lem- ming, with the body missing. The incubating female (Figure 2) did not leave the nest until we were within about $3 \mathrm{~m}$. There were seven eggs in a nest bowl lined with dried grasses and a few feathers (Figure 3). The nest was in a low space between tundra hummocks on the edge of a wet sedge meadow (Figure 2). There were two Common Eider (Somateria mollissima) nests within $20 \mathrm{~m}$ of the Short-eared Owl nest.

The following morning (28 June), an Arctic Fox (Vulpes lagopus) was observed hunting in the area for about half an hour, and both adult Short-eared Owls harassed it during that time, constantly swooping at it. The Arctic Fox disappeared from sight, then came into view again at the same time that a female Common Eider flew to a nearby pond. A check of the nest later the same day revealed that the Short-eared Owl was still incubating, but the nearest Common Eider nest had been predated. The Short-eared Owl nest was not checked again until August 10, at which time it was empty. Because we did not know the date on which the female began incubating, and the fact that nestlings will move some ways from the nest as young as 14-17 days of age (Committee on the Status of Endangered Wildlife in Canada 2008*), we cannot say whether the nest was successful or not, although the timing makes it possible.

The second Short-eared Owl nest was discovered on 23 July 2000 , approximately $4 \mathrm{~km}$ downstream of the confluence of the Muskox River and the Thomsen River $\left(73.856^{\circ} \mathrm{N}, 119.854^{\circ} \mathrm{W}\right)$, also in Aulavik National Park. Two adults were observed, and there were four pink-to-downy young in the nest. On both 27 and 28 July, a single adult was seen hunting in the meadows in the area. Since only the female is known to incubate 


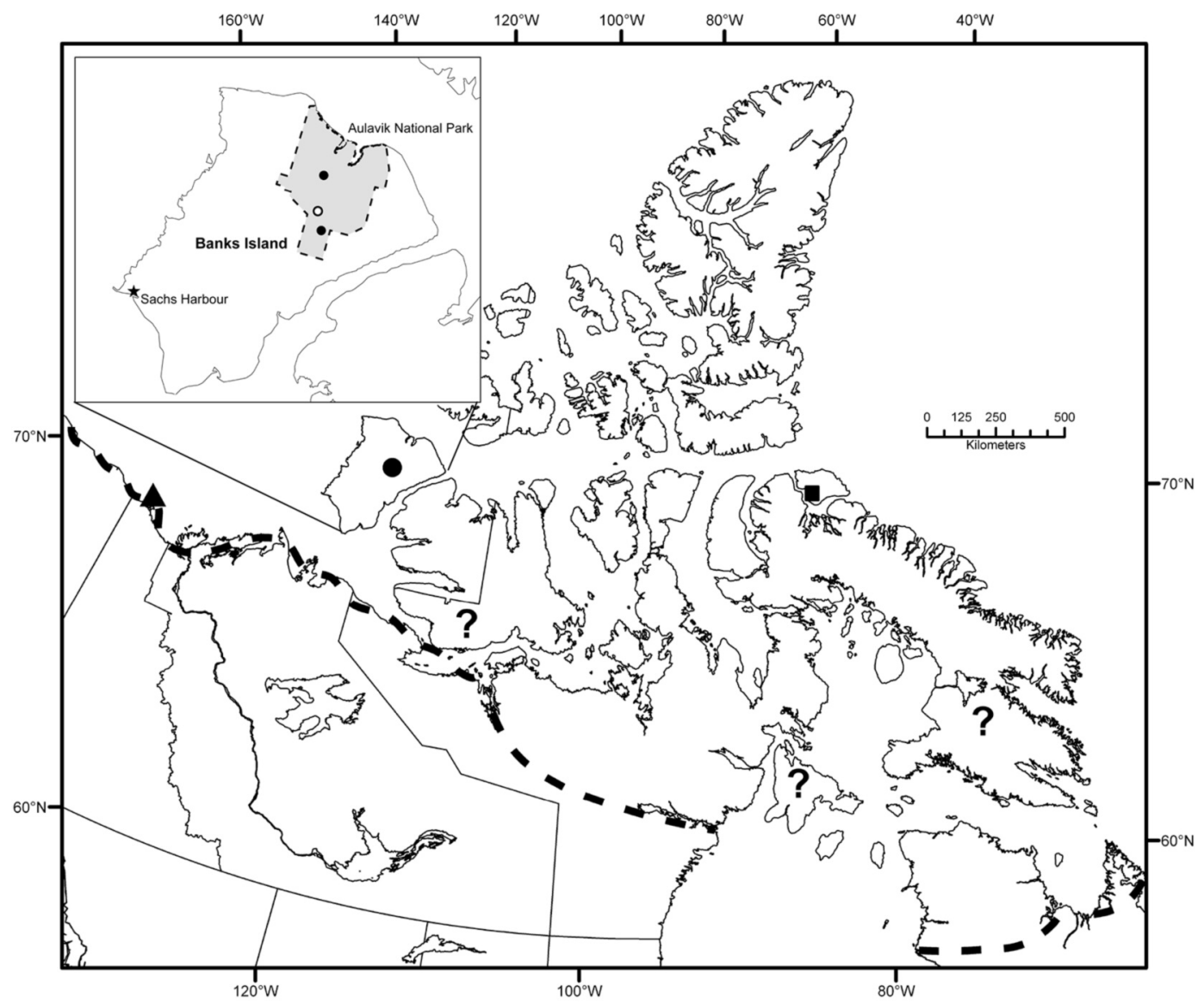

FIGURE 1. Location of the two Short-eared Owl, Asio flammeus, nests (black circles) and single observation (open circle) in Aulavik National Park of Canada, Banks Island, Northwest Territories, in June and July 2000; the observations by Reid et al. (2011) on Herschel Island, Yukon (black triangle); and the observation by Therrien (2010) on Bylot Island, Nunavut (black square). Dashed line shows northern limit of breeding range in Canada (Wiggins et al. 2006); question marks indicate possible breeding areas (Wiggins et al. 2006). Map adapted from Wiggins et al. (2006).

(Wiggins et al. 2006), we presume this was the male. It was periodically followed and dive-bombed by a Pomarine Jaeger (Stercorarius pomarinus). This nest was approximately $70 \mathrm{~km}$ north of the nest near Green Cabin.

On 2 July 2000, an adult was observed flying across the Thomsen River, between White Sand Creek and Shoran Lake $\left(73.436^{\circ} \mathrm{N}, 119.688^{\circ} \mathrm{W}\right)$. Because of the distance from the Green Cabin nest $(23 \mathrm{~km})$ and the Muskox River nest $(47 \mathrm{~km})$, this observation might indicate the presence of a third breeding pair of Shorteared Owls. Holt (1992) reported territory sizes of up to 242 ha in various studies.

In 2000, we also observed the following species for the first time on Banks Island, near the community of Sachs Harbour $\left(71.986^{\circ} \mathrm{N}, 125.250^{\circ} \mathrm{W}\right)$ : Merlin (Falco columbarius), Yellow-rumped Warbler (Setophaga

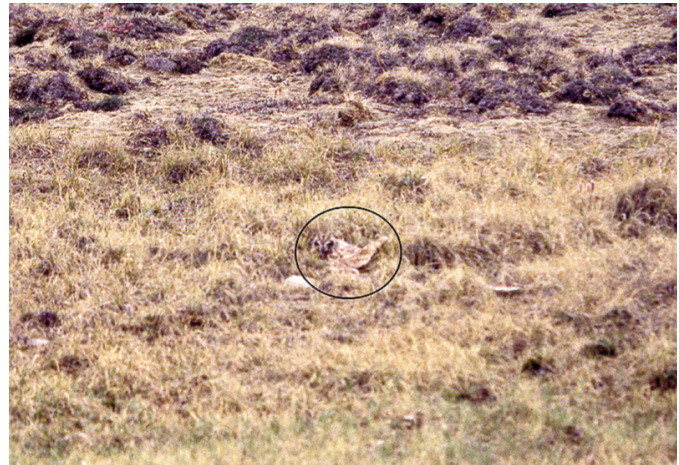

FIGURE 2. Short-eared Owl, Asio flammeus, female on nest (circle) near Green Cabin, Aulavik National Park of Canada, Banks Island, Northwest Territories, 27 June 2000. Photo: C. M. Smith . 
coronata), Chipping Sparrow (Spizella passerina) (June 11), and White-throated Sparrow (Zonotrichia albicollis) (June 22). All four species were from 400$750 \mathrm{~km}$ farther north than their known breeding ranges.

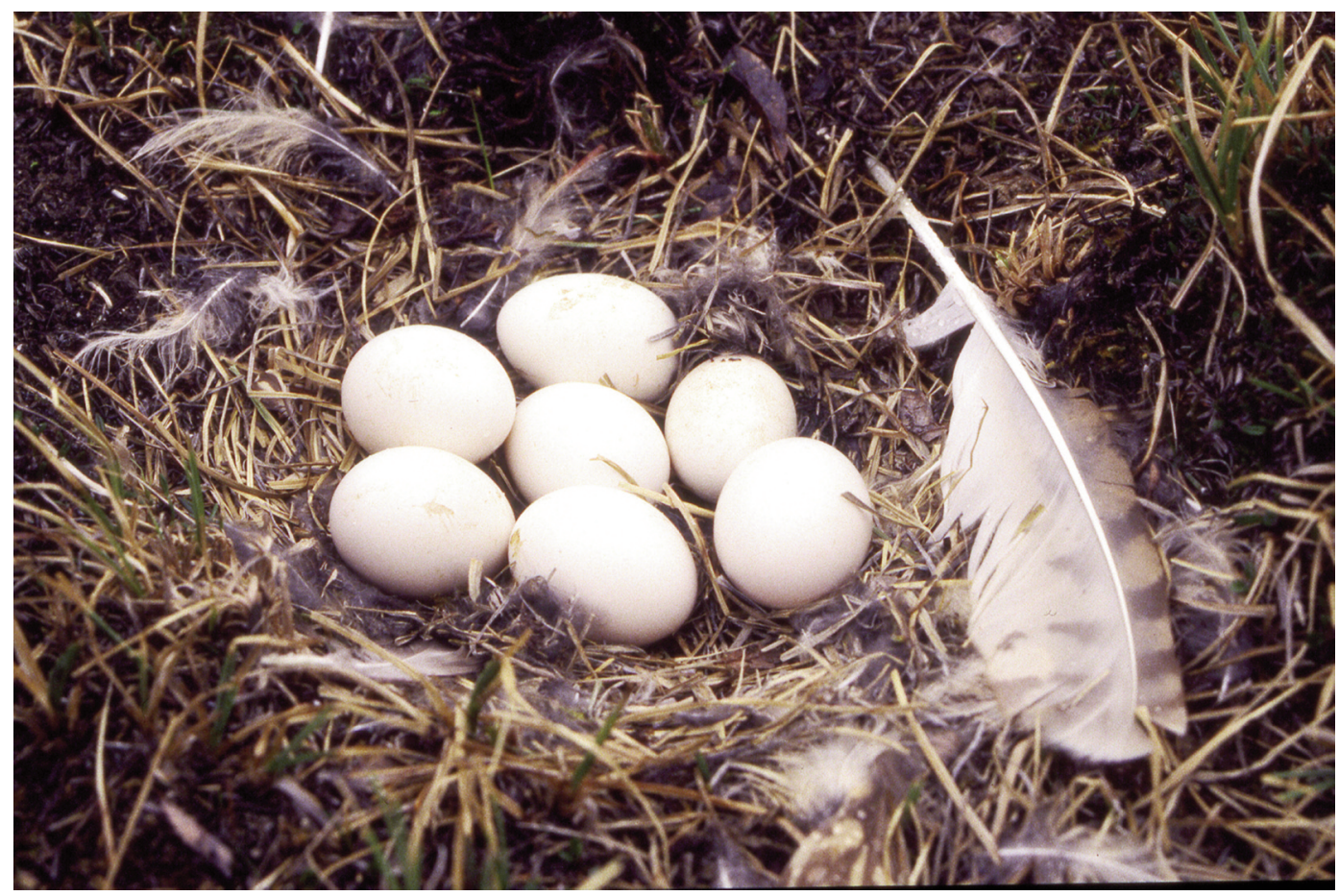

FIGURE 3. Short-eared Owl, Asio flammeus, nest near Green Cabin, Aulavik National Park of Canada, Banks Island, Northwest Territories, with seven eggs, 27 June 2000. Photo: C. M. Smith.

\section{Discussion}

The observations reported here confirm breeding by Short-eared Owls in the Canadian Arctic Archipelago, over $500 \mathrm{~km}$ north of the mainland. Along with the three nests documented on Herschel Island, Yukon, in 2007 and 2008 (Reid et al. 2011) and territorial behaviour observed on Bylot Island, Nunavut, in 2008 (Therrien 2010), these observations may provide evidence of northerly range expansion by this species. It is also possible that Short-eared Owls have been breeding on the islands for decades, but limited survey effort meant they were undetected. These may also have been extralimital breeding episodes in response to high numbers of prey (Pitelka et al. 1955; Reid et al. 2011), mainly Nearctic Brown Lemmings (Lemmus trimucronatus) and Northern Collared Lemmings (Dicrostonyx groenlandicus). In 2000, twice as many lemming nests were observed on monitoring plots near Green Cabin as in 1999 (Lawrence 2000*).

If this is a range expansion, it may be related to climatic factors. A rise of 2-3 Celsius degrees in mean annual temperature has been observed over the past 50 years in the western and central Canadian Arctic (Zhang et al. 2000; Furgal and Prowse 2008), and one of the biological responses is that the ranges of many species of plants and animals are expanding northward (Thomas and Lennon 1999; Intergovernmental Panel on Climate Change 2001; Parmesan and Yohe 2003; Brommer et al. 2012). The observations of the Merlin and three passerines for the first time on Banks Island support the hypothesis that climate change enabled the range expansion of the Short-eared Owl.

The Short-eared Owl is listed under the federal Species at Risk Act as a species of "special concern" because of population declines attributed to habitat conversion/degradation on both the wintering and the breeding grounds (Committee on the Status of Endangered Wildlife in Canada 2008*). It is unknown to what extent range expansion in the islands in the Arctic might compensate for this loss.

\section{Acknowledgements}

We thank Marianne Douglas and John Smol, who discovered the Green Cabin nest and reported it to the authors. We thank Peter Achuff and two anonymous reviewers for commenting on earlier drafts of this manuscript. 
Documents Cited (marked * in text)

Committee on the Status of Endangered Wildlife in Canada (COSEWIC). 2008. COSEWIC assessment and update status report on the Short-eared Owl Asio flammeus in Canada. Committee on the Status of Endangered Wildlife in Canada, Ottawa, Ontario. http://www.sararegistry.gc.ca /virtual_sara/files/cosewic/sr_shorteared_owl 0808 e.pdf.

Henry, J. D., and M. Mico. 1997. The birds of Aulavik National Park, Banks Island, Northwest Territories, Canada. Unpublished report. Parks Canada, Inuvik, North West Territories. http://www.taiga.net/reports/aulavikbirds/index .html.

Lawrence, A. 2000. Lemming monitoring, Aulavik National Park, 2000. Unpublished report. Parks Canada, Inuvik, North West Territories.

Wilkinson, P. F., C. G. Hickey, S. Skaggs, H. Sherwood, R. W. Howe, and R. Dawe. 1977. A biological and archaeological reconnaissance in north-central Banks Island, Northwest Territories, July-August 1977. Department of Indian Affairs and Northern Development, Montreal, Quebec.

Zoltai, S. C., D. J. Karasiuk, and G. W. Scotter. 1980. A natural resource survey of the Thomsen River area, Banks Island, North West Territories. Unpublished report prepared for Parks Canada by the Canadian Wildlife Service. Canadian Wildlife Service, Edmonton, Alberta.

\section{Literature Cited}

Brommer, J. E., A. Lehikoinen, and J. Valkama. 2012. The breeding ranges of central European and Arctic bird species move poleward. PLoS ONE 7: e43648.doi:10 .1371/journal.pone. 0043648 .

Furgal, C., and D. Prowse. 2008. Northern Canada. Pages 57-118 in From Impacts to Adaptation: Canada in a Changing Climate 2007. Edited by D. S. Lemmen, F. J. Warren, J. Lacroix, and E. Bush. Government of Canada, Ottawa, Ontario.
Holt, D. W. 1992. Notes on Short-eared Owl (Asio flammeus) nest sites, reproduction, and territory sizes in coastal Massachusetts. Canadian Field-Naturalist 106: 352-356.

Intergovernmental Panel on Climate Change (IPCC). 2001. Climate change 2001: Impacts, adaptation, and vulnerability. Edited by J. J. McCarthy, O. F. Canziani, N. A. Leary, D. J. Dokken, and K. S. White. Contribution of Working Group II to the Third Assessment Report of the Intergovernmental Panel on Climate Change. Published for the Intergovernmental Panel on Climate Change by Cambridge University Press, Cambridge, U.K.

Parmesan, C., and G. Yohe. 2003. A globally coherent fingerprint of climate change impacts across natural systems. Nature 421: 37.

Pitelka, F. A., P. Q. Tomich, and G. W. Treichel. 1955. Breeding behavior of jaegers and owls near Barrow, Alaska. Condor 57: 3-18.

Reid, D. G., F. I. Doyle, A. J. Kenney, and C. J. Krebs. 2011. Some observations of Short-eared Owl, Asio flammeus, ecology on arctic tundra, Yukon, Canada. Canadian FieldNaturalist 125 (4): 307-315.

Therrien, J-F. 2010. Territorial behavior of Short-eared Owls, Asio flammeus, at more than $1000 \mathrm{~km}$ north of their current breeding range in northeastern Canada: evidence of range expansion? Canadian Field-Naturalist 124 (1): 58-60.

Thomas, C. D., and J. J. Lennon. 1999. Birds extend their ranges northwards. Nature 399: 213.

Wiggins, D. A., D. W. Holt, and S. M. Leasure. 2006. Short-eared Owl (Asio flammeus). Revised. No. 62 in The Birds of North America. Edited by A. Poole. Cornell Laboratory of Ornithology, Ithaca, New York. http://bna.birds .cornell.edu/bna/species/062.

Zhang, X., L. A. Vincent, W. E. Hogg, and A. Niitsoo. 2000. Temperature and precipitation trends in Canada during the 20th century. Atmosphere-Ocean 38(3): 395-429.

Received 3 April 2013

Accepted 9 July 2013 